\title{
Appian, Cassius Dio and Seneca the Elder
}

Abstract: This paper examines the sources and methods of Appian and Cassius Dio and the likelihood that they used the Histories of Seneca the Elder as a source. It also considers the character and starting point of Seneca's Histories. Both Appian and Dio probably wrote up their histories from drafts which they compiled from their reading, but in other respects their aims and methods were very different. Cassius Dio's work was composed in the traditional mode of an annalistic Roman history from the foundation to his own time, while at the same time aspiring to high Greek literary standards. Dio read widely and seems to have drawn on multiple sources for most of his account. For the period which it covered the Elder Seneca's Histories may have been one of his sources. Appian's Roman History adopted a radically innovative structure, opening with a twelve-book account of the external wars of the Roman Republic, organized by region rather than linear chronology, and then passing to the violent internal discords initiated by the tribunate of Tiberius Gracchus and culminating in the establishment of monarchy, followed by a concluding overview of the wars of the imperial period. Unlike Dio, Appian seems to have followed a single main source for much of his work, including Dionysius for events down to 265, Polybius for events from 200 to 146 BC, and perhaps Posidonius for the immediately following period. For his more ample narrative after Caesar's death he seems to have used a wider range of sources, which may possibly have included the Elder Seneca. Appian's structure had much in common with that of Florus' much shorter history. The earlier of these writers must have influenced the later, but their priority cannot be determined. The view that the Elder Seneca's Histories served as the model for the structural features shared by Appian and Florus should be rejected. The starting point of Seneca's Histories was probably the war between Caesar and Pompey. His work had the traditional character of a Roman history limited to the recent past, was probably organized by the consular year, and so had nothing in common with the innovative structures of Appian and Florus.

The present volume celebrates a remarkable discovery: the identification of P.Herc. 1067 as part of the Elder Seneca's Histories, albeit in a highly fragmentary state. Since a copy of Seneca's work was available at Herculaneum in the later first century AD, it could well have been accessible also to Appian and to Cassius Dio, when they wrote their Roman histories in respectively the mid second and early third centuries. Dio indeed tells us that he wrote much of his history not far

Ә Open Access. (C) 2020 John W. Rich, published by De Gruyter. (c) BY-NC-ND This work is licensed under the Creative Commons Attribution-NonCommercial-NoDerivatives 4.0 License.

https://doi.org/10.1515/9783110688665-017 
from Herculaneum, in his villa at Capua (76.2.1). In the first two sections of this paper I seek to assess the likelihood that Appian and Dio used the Elder Seneca's Histories, and, if so, the extent of their use. In the third section I consider the account of Appian's relation to the Elder Seneca's Histories propounded by Rossbach, Hahn and Canfora and outline what in my view can be established about the character of Seneca's work.

For both Appian and Dio I shall be proceeding by a somewhat roundabout route, via an overview of their sources and methods. Discussion of Appian's sources has dealt in particular with his account of the civil wars, and for Dio there has been a similar concentration on his narrative of the late Republic and early Empire. This focus is natural enough: for each writer, these are both the best preserved and the most historically significant parts of their works. Unfortunately, the sources they used there are mostly lost, and as a result attempts to identify them have often tended to be over-speculative. However, the enquiry can be put on a firmer footing by taking full account of what the writers themselves say about their methods of work and by considering their treatment of earlier periods, for which their narratives can be compared with what survives of Livy, Dionysius and Polybius.

\section{Cassius Dio}

As a stylist, Dio modeled himself on the classical Greek historians, particularly Thucydides, but in its structure his history conformed to the oldest of the Roman historical genres: his eighty books narrated the deeds of the Romans from the foundation of the city to his own time, and the material was arranged annalistically, by consular years. ${ }^{1}$ Dio only refers to two sources by name, the autobiographies of Augustus and Hadrian. ${ }^{2}$ However, he does make some illuminating statements about his methods of work, in particular that he 'spent ten years in collecting all the achievements of the Romans from the beginning to the death of

1 Millar (1964) remains the classic study of Cassius Dio and his history. Important recent contributions include Kemezis (2014) 90-149; Lange/Madsen (2016); Fromentin et all. (2016); BurdenStrevens/Lindholmer (2018); Osgood/Baron (2019); Madsen (2020). Several further collective volumes are forthcoming in Brill's Historiography of Rome and its Empire series. On Dio's use of annalistic organization see Swan (1987), (2004) 17-21; Rich (2016).

2 D.C. 44.35.3, 66.17.1, 69.11.2. 
(Septimius) Severus, and another twelve in writing my history'. ${ }^{3}$ The chronological implications of this statement have been much discussed: in my view, the twenty-two years of research and writing are best dated to around 201 to $223 .{ }^{4} \mathrm{No}$ less important are what it tells us about how Dio worked, spending ten years gathering materials and only then starting to compose.

Dio must have accumulated notes and drafts during the long initial period of research. Other evidence attests ancient writers' use of such aids: thus the Younger Pliny tells us that his uncle 'never read a book without making excerpts', while Lucian recommends that a historian should first collect his materials, then weave them together as a draft (hypomnema), and only then work over his draft to give it artistic finish. ${ }^{5}$

Dio claimed in his preface that he had 'read pretty nearly everything which has been written about (the Romans) by anyone'. ${ }^{6}$ This will have been a gross exaggeration, but he must still have read very widely during the initial ten years. This reading will not have been confined to earlier histories: Dio was to make substantial use, for example, of Cicero's Philippics in the huge debate which he composed for Cicero and Calenus. However, earlier annalistic histories must have provided his principal source of material.

It has sometimes been supposed that in the final stage in which he produced the finished composition Dio worked mainly from just one source at a time, with the full text of the source open in front of him. However, if he followed this method, much of his effort in the ten long years devoted to gathering material would have been wasted. No doubt he may sometimes have reverted to the original texts, but to my mind it is more likely that in the composition stage Dio worked chiefly from his accumulated notes and drafts. Such a method will have helped to shape the character of his work, and will have resulted in the deployment of a diverse range of source material. There will have been some points where Dio's narrative derived mainly from a single source, but more often the

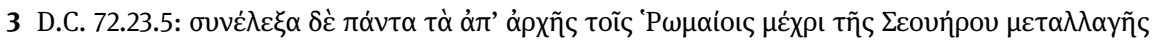

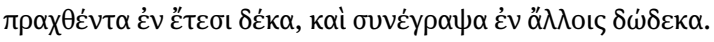

4 Rich (1990) 3-4; Swan (2004) 28-33. For a later dating see Barnes (1984), Letta (2019); for an earlier starting point see now Kemezis (2014) 282-293.

5 Plin. epist. 3.5.10; Lucian Hist. Cons. 48. On ancient writers' use of drafts see Avenarius (1956) 85-104; Skydsgaard (1968) 101-116; Dorandi (2000) 5-50; Pelling (2002) 19-25, 29, 40-43, 6590.

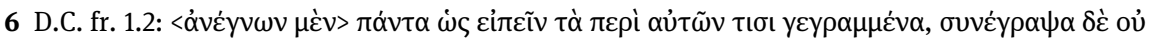

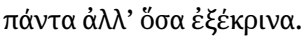


notes from which Dio produced his finished composition will have been put together from several sources drawn from his wide reading. ${ }^{7}$

The extant part of Dio's history begins with Book 36, in 69 BC. Before that, we are dependent on excerpts in various Byzantine collections and the epitome of Zonaras. However, enough survives by these means to enable us to make an informed comparison with Livy and Dionysius. The results seem to me to support my conclusions about Dio's methods. As Schwartz long ago showed, there are a good many points of agreement with Livy, and more with Dionysius, but much of Dio's narrative diverges from them both. Urso has even suggested that Dio may have been consciously seeking to present an alternative version to Livy's. It is most unlikely that for early Roman history Dio depended on a single, unknown, main source. Much more probably, he drew on both Livy and Dionysius and also on several of their annalistic predecessors. ${ }^{8}$

Dio's account of the late Republic and early empire also fits well with this conception of his work as written up from notes drawn from wide reading. Such a method can help to explain both the strong interpretative shaping which Dio gave to his material, with its heavy stress on protagonists' motivations, and his sometimes notable errors, such as the misdating of Egnatius Rufus' career or the omission of the Conference of Luca. Attempts to identify a single source followed by Dio for extensive stretches have failed: thus Schwartz's doctrine that the later books of Livy served as Dio's primary source was refuted by Manuwald. ${ }^{9}$

When he reached the imperial period, Dio switched to a partly biographical mode: he still narrated emperors' reigns year by year, but these annalistic sections were framed by opening and closing sections assessing the emperor's character and mode of government, a structural device which may have owed something to Suetonius' example. ${ }^{10}$ As a result, the annalistic sections are often now comparatively thin, but Swan (1987) shows that this was not for lack of evidence, but from Dio's choice. Even here, however, there is no need to suppose that Dio confined himself to just one of the earlier historians (for example, Aufidius Bassus) as his main source, rather than drawing on several of them.

If these conclusions are correct, it is not at all unlikely that Dio's wide reading included the Elder Seneca's Histories, and that some material which found its

7 For this view of Dio's methods of work see further Rich (1989) 89-92, (1990) 5-11, (2015) 7072. See also Millar (1964) 32-40; Gowing (1992) 43-44; Swan (1997), (2004) 17-23.

8 Schwartz (1899) 1692-1694; Libourel (1974); Urso (2016); (2018). On Dio's sources in his early books see also the further studies in Fromentin et all. (2016) 113-231.

9 Schwartz (1899) 1697-1714; Manuwald (1979) 168-254. Egnatius Rufus: C.D. 53.24.4-6, with Rich (1990) 159. I discuss Appian's and Dio's treatment of the late Republic at Rich (forthcoming). 10 On Dio's use of the biographical mode, or “biostructuring”, see Pelling (1997). 
way into his finished history had been drawn by him from this source. Any attempt to identify such material must be the merest speculation. However, one tempting guess is that Dio may have turned to Seneca's Histories for some of his vivid insider gossip on court politics under Augustus. Such material cannot have been included by writers who published under Augustus or Tiberius, like Livy or Cremutius Cordus. Seneca, who did not intend to publish his Histories in his lifetime, may have felt under less constraint, and, as his other writings show, had intimate knowledge of the court.

Seneca's Histories may well have been Dio's source for the conspiracy of Cinna and Augustus' display of clemency in response at Livia's urging, an episode which Dio dates to AD 4 (C.D. 55.14-21). Our only other evidence for this event is the Younger Seneca's De clementia (1.9), whose indications imply that it took place during Augustus' stay in Gaul in 16-13 BC. It is plausible to suppose that the philosopher was indebted to his father's Histories for the tale. ${ }^{11}$ Dio has commonly been held to have taken it (directly or indirectly) from the De clementia, but the Elder Seneca's Histories are a more likely source for him as well. No doubt the historian, like his son, dated the episode much earlier than Dio, and Dio's dating is probably another instance of confusion in his notes. ${ }^{12}$

\section{Appian}

The Roman history of Appian of Alexandria was very different in character from that of Cassius Dio. While Dio' work conformed to the traditional format, recounting the Romans' deeds at home and at war by the consular year from the foundation to his own time, Appian offered a radically novel alternative. He omitted domestic affairs except where they involved bloodshed, and adopted a structure in which chronological linearity was subordinated to region and theme. Prefatory statements show that the planned structure evolved as the work progressed. ${ }^{13}$

Appian's completed Roman History comprised two groups of twelve books. The first twelve dealt with the Romans' external wars and conquests, covering all the regions with which they came into ultimately victorious conflict up to the 50s $\mathrm{BC}$. The fundamental organizing principle was that the Romans' dealings with each region were narrated in a single book from the time of the first encounter up

11 So Rossbach (1888) 172; Canfora (2015) 177-179.

12 On Dio's version see especially Swan (2004) 147-155; Adler (2011).

13 For the book structure of Appian's history see Brodersen (1993) 341-348, and on the structure's evolution and background see Bucher (2000), Osgood (2015) and Welch (2019). 
to the completion of the conquest. Thus some books, for example those dealing with Gaul and Spain, cover very extended periods, and between the books the narrative jumps back and forth over time. Appian did, however, show flexibility in the application of this scheme: thus he did not attempt to treat later warfare in central and southern Italy together with the initial wars of conquest, but instead assigned a single book (the Annibaike) to the Hannibalic war in Italy. The twelve books form three sub-groups of four books each. The first four covered the Romans' wars under the kings (Basilike), during the conquest of central and southern Italy (Italike, Saunitike) and against the Gauls from their sack of Rome down to Caesar's conquests (Keltike). Books 5-8 dealt with the Romans' wars against the Carthaginians and with their further conflicts with the western peoples first encountered during those wars (Sikelike, Iberike, Annibaike, Libyke), while Books 9-12 covered their main wars in the East (Makedonike, Hellenike, Syriake, Mithridateios). Various regions which did not fit into the twelve-book scheme were rather clumsily included as supplements to four of the books (Nesiotike, Nomadike, Illyrike, Ionike). Five of the twelve books survive intact (Iberike, Annibaike, Libyke, Syriake, Mithridateios), along with the short prefatory book and the supplementary Illyrike. Fragments survive from all of the rest except for the Hellenike and Ionike. ${ }^{14}$

The second group of twelve books opens with the five extant books of the Emphylia, covering the internal disorders from the tribunate of Tiberius Gracchus in 133 to the defeat and death of Sextus Pompeius in 35 BC. Since the Renaissance, the title Emphylia has normally been translated as Civil Wars, but this is misleading since Appian included not just the civil wars fought between opposing Roman armies, but also other internal upheavals which led to bloodshed, and so in what follows I shall continue to use Appian's term Emphylia, abbreviating it as E.

The point has particular importance for the structure of the first book of the Emphylia. Appian explains at the outset that he has started with Tiberius Gracchus because he and his associates were the first to be killed in civil strife (stasis), and from that time such disorders got progressively worse until they took the form of open warfare (E.1.2.4-6). From Tiberius Gracchus he passes to his brother Gaius and then to Saturninus, identifying the conflicts between them and their opponents as three successive episodes of stasis or 'internal action' (ع́pyov ع́ $\mu \varphi v$ $\lambda$ ıov). ${ }^{15}$ Appian then turns to the Social War, justifying its inclusion at this point

14 On the Parthike, promised by Appian but apparently never composed (Syr. 51.260; E. 2.18.67, 5.65.276), and on the spurious Parthian book preserved in manuscripts of Appian's work see now Canfora (2015) 70-78; Mallan (2017).

15 App. E. 1.27.121, 33.150. 
on the grounds that it arose from the stasis in Rome and gave rise to worse stasis in which leaders resorted to armies (E. 1.34.150-1). The initiative was taken by Sulla in 88 when he led his army against Rome to resolve his conflict with Marius and Sulpicius. Appian comments: 'Thus the staseis progressed from strife and rivalry to murders and from murders to full-scale wars, and this was the first army of Roman citizens to invade their country as though it were enemy land'. ${ }^{16}$

The Emphylia were followed by the four books of the Egyptian history, which sadly are almost completely lost. These covered both the final civil war, at Actium and Alexandria, and the resulting conquest of Egypt. Appian evidently regarded these books as the culmination of the whole work, since they dealt simultaneously with the ending of the civil wars through the establishment of monarchy and the completion of the Roman empire by the conquest of his own homeland. ${ }^{17}$

By a late change of plan, Appian added three further books, dealing with the wars of the emperors, especially Trajan. These too are almost completely lost.

The earlier large-scale works covering all or most of Roman history followed the annalistic format, but the much shorter account in Latin by Florus, also composed during the mid second century AD, shows striking similarities to Appian's scheme. Both author's prefaces offer the same periodization of Roman history, according to which 500 years had elapsed from the foundation to the completion of the conquest of Italy; the following two hundred years had seen the extension of Roman power over most of the world and the establishment of monarchy; and nearly two hundred more years had passed by their own time. ${ }^{18}$ The first part of Florus' work is, like Appian's, concerned almost exclusively with the external wars of the Republic (epit. 1.4-16, 18-47 = 1.10-21, 2.1-3.12). ${ }^{19}$ Like Appian, Florus then turns to the 'internal upheavals' (domesticos motus) of the Late Republic, beginning with what he calls the seditiones of the Gracchi and Saturninus (epit.

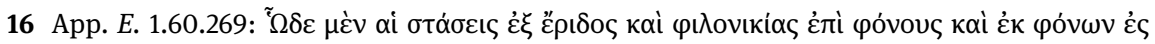

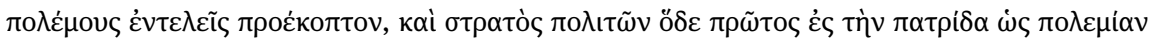

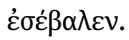

17 App. Praef. 14.60, E. 1.5.20-21, 1.6.25; Luce (1964); Canfora (2015) 125-136.

18 App. Praef. 6-7.19-24, cf. 9.34, 11.44; Flor. epit. 1 praef. 5-8, cf. epit. 1.34, 47, 2.34 (= 2.19.23 , 3.12.2-3, 4.12.64). Various emendations are required in Florus' preface: see Hirschfeld (1899) 543-4; Jal (1967) 1. LXXX-LXXXII; Hose (1994) 58-9. I give references to both the two-book and four-book editions of Florus' history: both book divisions have manuscript authority, but editors have subdivided chapters into sections only for the four-book version. For convenience, I use the two-book division in subsequent discussion of the structure of Florus' work.

19 Florus' work opens with the kings and the establishment of the Republic (epit. 1.1-3 = 1.110 ), and includes a short account of the seditiones of the early Republic (epit. $1.17=1.22-26$ ), using the term seditio at epit. 1.22.2, 25.1, 26.5. 
$2.1-4=3.13-16$ ), ${ }^{20}$ and then continuing with the Social War (epit. $2.5-6=3.17-18$ ) and the long series of civil wars, starting with the war between Marius and Sulla (epit. 2.9-18, 21 = 3.21-4.8, 4.11). ${ }^{21}$ Again like Appian's, Florus' history concludes with a short account of imperial wars (epit. $2.22-34=4.12$ ).

There are also some notable differences between the two works. Florus' treatment of imperial wars was limited to those of Augustus, whereas Appian's extended to Trajan. Unlike Appian's, Florus' narrative of the Republic's external wars makes only limited use of geographical arrangement, and mainly follows linear chronology. ${ }^{22}$ A central (and much discussed) part is played in the structuring of Florus' work by the biological metaphor of the four ages of the Roman people (infantia, adulescentia, iuuentus, senectus), but there is no trace of this in Appian. ${ }^{23}$

The structural similarities between Florus' and Appian's histories are, nonetheless, too striking for coincidence, and are most easily explained by supposing that one of these writers influenced the other. Unfortunately the direction of influence cannot be firmly established: most scholars have held that Florus' history was composed earlier than Appian's, but the chronological indications are too slim to settle the point. ${ }^{24}$ The alternative possibility of common derivation from a shared source is discussed in the next section.

The following passage in Appian's Preface (12.45-13.49) gives illuminating information on how he came to write his history on regional principles:

20 Domesticos motus: Flor. epit. 1.47 (=3.12.14), making a sharp contrast with the 'external and just wars' (ab externis iustisque bellis), as at epit. $1.34(=2.19 .5)$. Florus uses seditio of the actions of the Gracchi and Saturninus at epit. 1.47, $2.1(=3.12 .9,13.1)$. The term is also used in the chapter headings, but these were inserted by a late antique grammarian (Jal (1967) 1. XIV-VIII).

21 Florus inserts the various slave wars between the Social War and the civil wars (epit. $2.7-8=$ 3.19-20).

22 On Florus' use of geographical arrangement see Hose (1994) 77-80.

23 For Florus' "biological" scheme see epit. 1 praef. 4-8 and epit. 1.18, 34, 47 (= 2.1.1-2, 2.19.23, 3.12.1-3). Discussions include Häussler (1964); Jal (1967) 1.LXIX-CXI; Alonso-Núñez (1982); Hose (1994) 65-76; Bessone (1993b) 87-97, (1996) 31-41, (2008); ten Berge (2019).

24 On Appian's date of composition see Brodersen (1993) 353-354; Bucher (2000) 415-416. Florus is held to have written under Hadrian by e.g. Garzetti (1964); Jal (1967) 1. CII-CXI; Hose (1994) 56-61. Other datings for Florus' history include: under Antoninus Pius, shortly before Appian (so Bessone (1993b) 91-97, (1996) 133 n. 3); under Marcus Aurelius, with Appian used as a structural model (so Hinard (2008) XIX-XXXVII). Florus cannot be redated to the Augustan period, as has sometimes been proposed: see Bessone (1996) 123-132; Berti, in this volume supra $119 \mathrm{n}$. 66. 


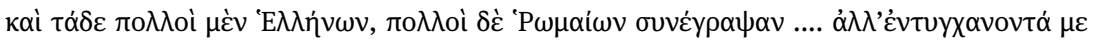

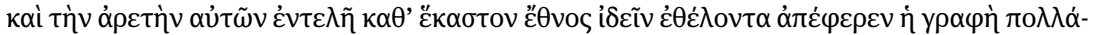

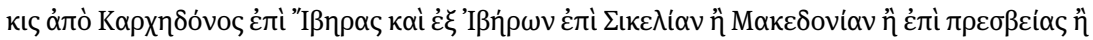

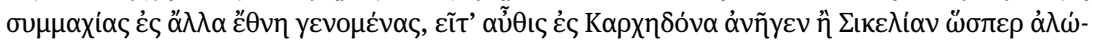

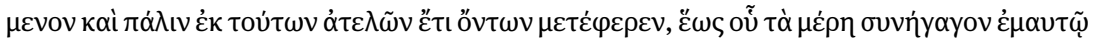

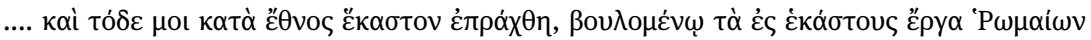

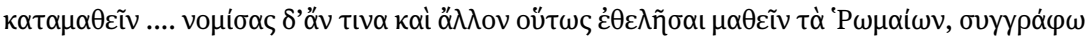

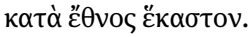

This passage has often been misinterpreted through misunderstanding of the

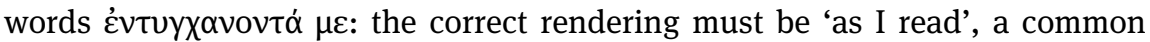
sense of the verb in post-classical Greek. Appian tells us that, as he read Roman history, he became frustrated. He wanted 'to get a complete picture of the Romans' valour in their dealings with each nation', but found that 'the account' was taking him from nation to nation and back like a wanderer, until I brought the parts together for myself ... for each nation'. It then occurred to him that others too would welcome such a version, and accordingly he set himself to 'composing the Romans' history nation by nation'.

Appian's suggestion that his enterprise was originally undertaken just for his own private use may be disingenuous, but there is no reason to doubt his claim that his procedure was first to assemble the materials on the Roman conquest nation by nation, and then to write them up as a history. Thus, as for Dio, Appian's reported method of composition involved two stages, but the nature of their activity in the first stage will have been radically different. Dio's task at that point was to bring together the materials for his chronological narrative from a wide range of sources, of which the most important would have been following the same arrangement by the consular year which he adopted for his own history. By contrast, Appian's primary task in this initial stage was to divide up the chronologically ordered material provided by his predecessors to fit his preferred ethnic and regional structure. To achieve this, he must have produced notes and drafts organized in accordance with his desired structure, and it would then have been natural for him, as for Dio, to work mainly from this material, rather than from the original sources, when he moved on to compose the finished history. As for Dio, composition from notes and drafts may help to explain features of Appian's history as we know it - both the strong interpretative shaping which he gave to his material and his frequent errors. ${ }^{25}$

The quoted passage begins by observing that 'many Greek and Roman writers have recounted' the Romans' conquest of their empire. However, when he goes

25 On Appian's methods of work see further Rich (2015), especially 69-72. 
on to describe his experience as a frustrated reader, Appian seems instead to be speaking just of a single 'account' ( $\dot{\eta}$ y $\rho \propto \varphi \grave{\eta})$. This conveys the impression that in his first stage of reordering his material Appian tended to work from a single main source. He cannot have meant, as Gelzer (1957) supposed, that he followed the same source throughout his work, but his language does carry the implication that he did so for extended periods of Roman history. It would not be surprising if he proceeded in this way. An author offering yet another annalistic Roman history might feel obliged to innovate in the way he selected and combined material from various earlier accounts. However, Appian's chief innovation came in his reordering the material on ethno-regional lines, and he need have felt no scruple about drawing it mainly from a single well-regarded authority when one was available. Our other evidence indicates that this was in fact how Appian proceeded over much of his work.

Tab. 7: Historical periods and identifiable main sources in Appian's extant Roman History

\begin{tabular}{lll}
\hline BC & Extant coverage in Appian & Main sources \\
\hline To 265 & Basil., Ital., Samn. (all frags.); Gall. fr. 1.1-4, 2-11 & Dionysius \\
264-201 & $\begin{array}{l}\text { Sic. fr. 1-5; Iber. 4-38; Hann. (all); Pun. 3-66; Mac.fr. 1-4; Ill. } \\
\text { 7-8 }\end{array}$ & \\
200-146 & $\begin{array}{l}\text { Hisp. 39-63; Lib. 67-135; Mac. fr. 4-19; Ill. 9, 11; Syr. 1-47; } \\
\text { Mith. 3-7 }\end{array}$ & Polybius \\
146-50 & $\begin{array}{l}\text { Gall. fr. 1.5-13, 12-22; Sic. (Nesiot.) fr. 6-7; Hisp. 64-102; } \\
\text { Pun. 136; Num. (all frags.); Ill. 4-5, 10-11, 30; Syr. 48-51; }\end{array}$ \\
& $\begin{array}{l}\text { Mith. 10-120; Emphylia 1.7 - 2.30 } \\
\text { From 50 }\end{array}$ & $\begin{array}{l}\text { Hisp. 102; Lib. 136; Ill. 13-30; Mith. 121; Emphylia 2.31 - } \\
\text { 5.145; frs. 13-19 (Egyptian and imperial books) }\end{array}$ \\
\hline
\end{tabular}

The table above shows the coverage of five successive historical periods in what survives of Appian's history. For two of these periods the bulk of Appian's material derives, as has long been recognized, from a single source. Appian dealt with the conquest of Italy in his first three books and the first part of his fourth. All these books survive only in fragments, but enough is preserved of them and of Dionysius' history to show that most of the material in these books comes from Dionysius. What survives of Appian's coverage of the Romans' wars in the years $200-146$ BC is spread over six books: in all of these the bulk of the material comes from Polybius, as is shown by the fragments of Polybius and by portions of Livy and Diodorus for which Polybius was certainly the source. The point emerges particularly clearly for Appian's account of the Romans' war with Antiochus III, 
which survives intact (Syr. 1-44) and for which almost all of Polybius' account is available to us from fragments or through Livy and Diodorus.

The natural conclusion from these facts is that Appian himself followed respectively Dionysius and Polybius directly as his main source for these periods. For most of the nineteenth century this was well understood: thus, for example, Niebuhr, Nissen and Hannak all asserted Appian's direct use of Dionysius and/or Polybius. ${ }^{26}$ This consensus was challenged by Schwartz, in a discussion of Appian's sources which was to prove hugely influential. Schwartz argued that Appian's divergences from Dionysius and Polybius are so great that he cannot have been responsible for them himself and must have been using these writers through a later intermediary. ${ }^{27}$ The majority of later scholars have accepted his case at least for the Polybian material. However, Schulten was an early dissenter, and Appian's direct use of Polybius in his account of the war with Antiochus has been upheld by Brodersen in his excellent edition of this part of the Syriake and by me in a recent paper. ${ }^{28}$

Since Schwartz, the question of Appian's sources has been mainly discussed in relation to individual books rather than his history overall. A notable exception is a much cited paper by Hahn, but its methodology is unfortunately flawed: Hahn assigns individual books to sources on the basis of indicators which are more likely to reflect Appian's own choices, namely the incidence of speeches and Olympiad dates. ${ }^{29}$

In my view, the hypothesis that Appian was using Dionysius and Polybius only through an intermediary should be abandoned. In the first place, no convincing suggestions have been made as to who the intermediary may have been. Secondly, there is no need whatever to postulate an intermediary. The divergences between Appian's version and Dionysius' and Polybius' originals may either be self-generated (whether through error or by deliberate choice) or result from the use of additional sources. In either case, there is no good reason to suppose that Appian himself could not have been responsible. Schwartz reached his view because he conceived of Appian as a mere compiler, with no mind of his own, but this conception has been exploded by recent research. Appian himself will have been perfectly capable of reading Dionysius and Polybius as his primary sources and using them with a good deal of freedom.

26 Niebuhr (1828/1870) 46; Nissen (1863) 113-117; Hannak (1869).

27 Schwartz (1896) 217-222.

28 Schulten (1905) 77-106; Brodersen (1991); Rich (2015). See also now McGing (2018) for Appian's direct use of Polybius on the Third Punic War.

29 Hahn (1982). 
As the analyses by Brodersen and in my recent paper have shown, we can observe in detail how Appian handled his Polybian original in his account of the war with Antiochus by comparing it with the surviving fragments of Polybius and with the narratives of Livy and Diodorus. For some episodes Appian reproduces Polybius relatively fully and accurately, but elsewhere he compresses heavily. This leads to a good deal of distortion, and so too does the reshaping that Appian carries out to produce a coherent monographic narrative of the war. There are a good many careless slips, especially over names, often perhaps the result of working from notes. Another source of distortion is Appian's own emphasis on certain themes which he uses to structure his narrative: the greatness of Antiochus' reputation and the unexpected ease of the Romans' victory; Antiochus' greed and the two sides' mutual suspicion; Antiochus' folly and the contrasting good sense of Hannibal and Scipio Africanus. Two passages, both relating to Scipio (Syr. 11-12, 40-41), are certainly introduced from another source, in my view best identified as Plutarch's lost life. Further intrusions from other sources are possible, but in my view it is more likely that Appian himself was responsible for all the other divergences from Polybius in this part of his work. ${ }^{30}$

So full a comparison between Appian and his main source is only possible for the Antiochus narrative, but, as I hope to show in detail elsewhere, enough survives for his other books with Polybian material and for those which drew on Dionysius to show that there too he used these writers directly and in much the same way as for his account of the war with Antiochus. ${ }^{31}$

Thus for two important historical periods Appian used an authoritative Greek writer, first Dionysius and later Polybius, as his main source, treating this source with considerable freedom, but only occasionally introducing material drawn from elsewhere. How did he proceed for the other periods for which there is little scope for comparing his account with its source?

For the years 264-201 BC, the period of the First and Second Punic Wars, Appian did not follow Polybius, but opted instead for a Roman source or sources. This may seem surprising in view of his later devotion to Polybius, but there were good precedents: Diodorus and Plutarch had done the same, and evidently Polybius was (wrongly) felt to have less authority for this period. Appian's main source for the Second Punic War has been much discussed, but we can only speculate. ${ }^{32}$ Fabius Pictor, favoured by some, can certainly be excluded. The strongest candidate may be Coelius Antipater's monograph on the war, composed in the

30 For a different view see Goukowsky (2007) CXIII-CXXV; (2016) CII-CIV.

31 See Rich (2015) 112-113.

32 See further Leidl (1993) 446-459. 
later second century BC: on several points, Appian's version agrees with that attributed to Coelius by Livy.

Appian wrote at length about events of the late second and early first century in several of his external books and in the first book of the Emphylia. Here Appian's account cannot be compared with a predecessor, but much of it shared a common source with Plutarch. Polybius' history ended in 146 BC, and there is an obvious candidate for Appian to have turned to as his next main source, namely Polybius' continuator Posidonius. Much less of Posidonius' history survives, but in antiquity his authority was comparable to Polybius': both Livy and Diodorus appear to have turned from Polybius to Posidonius. That Appian did the same was held by Niebuhr and argued in detail by Busolt. ${ }^{33}$ However, Schwartz rejected the claim, ${ }^{34}$ and subsequently, although Posidonius has continued to get some support as a source for Appian's Spanish and Mithridatic narratives, he has been generally disregarded as a possible source for the Emphylia. In my view, this needs reconsideration. The principal objection to identifying Posidonius as a main source for the first book of the Emphylia has been alleged divergences on some topics, for example their judgement of C. Gracchus, between Appian and Diodorus, who has usually been supposed to be faithfully following Posidonius. The discrepancies may not be as serious as has been claimed, and several recent writers have credited Diodorus with greater independence than was previously held. ${ }^{35}$ There are considerable attractions in identifying Posidonius as the source of the common material in Appian and Plutarch on the late second and early first century. For example, Posidonius seems to me the most plausible source for the excursus on the Roman public lands which precedes both Appian's and Plutarch's accounts of the tribunate of Tiberius Gracchus.

Another candidate who has received notable support as a main source of the Emphylia from the first book on is Asinius Pollio, first proposed by Meyer and argued at length by Gabba. ${ }^{36}$ However, the doctrine that Appian was already using Pollio as a main source in the first book has now been generally and rightly abandoned. Horace's reference to Pollio as writing of 'civil conflict beginning from Metellus' consulship' (motum ex Metello consule ciuicum) shows that he began his history with the consulship of Metellus Celer in $60 \mathrm{BC}$ and the formation

33 Niebuhr (1828/1870) 46; Busolt (1890).

34 Schwartz (1896) 222.

35 On Diodorus' use of Posidonius for events after 146 see now Wirth (2007); Goukowsky (2014) X-XX. In general on Diodorus' independence in handling his sources see Sacks (1990); Hau (2009); Rathmann (2016); Muntz (2017) especially 14-21; Hau et all. (2018). On the difficulty of reconstructing Posidonius' history see Clarke (1999) 130-139.

36 Meyer (1894) 12; Gabba (1956) especially 83-88. 
in that year of the political alliance whose collapse was to bring Pompey and Caesar to civil war. ${ }^{37}$ The notion that this was preceded by an extended introduction starting from the tribunate of Tiberius Gracchus in 133 has no plausibility. ${ }^{38}$

If Appian did use Posidonius' history as a main source, he would have had to look elsewhere when it finished in or soon after $86 \mathrm{BC}$, and it seems that after this he was obliged to depend on Roman writers. Despite recent objections, Pollio's history still seems to me the most likely source for the material common to Appian and Plutarch on the 50s and 40s BC in the second and later books of the Emphylia. ${ }^{39}$

After the outbreak of the war between Pompey and Caesar, and still more after Caesar's death, Appian's narrative in the Emphylia changes gear. He now writes in much greater detail than before and on a larger scale than he seems originally to have planned. Speeches, absent from the earlier part of the Emphylia, now become very common, and there are more references to disagreement in his sources. It is likely that Appian's detailed work on this part of his history was only carried out at a fairly late stage, after he had finished work on the twelve books of external wars. Those books had dealt almost exclusively with the period down to the 50s BC, so that by now the chronology of events no longer required him to switch between books. The only exception is the supplementary book on the Illyrian Wars, which was probably a late addition prompted by Appian's encounter with Augustus' autobiography. ${ }^{40}$ Moreover, in these later books of the Emphylia, Appian was approaching the climax of the whole work, to be achieved in the lost Egyptian books.

It is thus likely that at this stage in the Emphylia Appian, by now a seasoned historian, adopted a modified method in which he made more use of multiple sources. He explicitly acknowledges several sources here, and probably used others without explicit citation. ${ }^{41}$ One of these may have been the Histories of Seneca the Elder.

The above discussion has not addressed another view propounded by a number of scholars, namely that both Appian and Florus used the Seneca the Elder's

37 Hor. carm. 2.1.1-8. Against the view of Woodman (2003) 202-212 that the reference is to the consulship of Metellus Numidicus in 109 BC see Drummond (2013) 437-438.

38 See further Cuff (1967) 185-188; Drummond (2013) 438.

39 See now especially Pelling (2002) 3-18, (2011a) 44-47. Appian's dependence on Pollio is doubted by Drummond (2013) 439-440 and disputed by Westall (2013); (2015) 143-145, 156.

40 Cf. App. Ill. 14.42; E. 4.110.463, 5.45.191, 5.145.602.

41 On Appian's references to sources in this part of his work see Magnino (1993) 537-545; Westall (2015) 130-146. 
Histories as their main source for their accounts of the internal upheavals and ensuing civil wars from $133 \mathrm{BC}$ on. It is to this doctrine that we must now turn.

\section{Seneca the Elder, Florus and Appian}

In November 1816, shortly after his arrival in Rome as Prussian ambassador to the papal court, Niebuhr discovered in a palimpsest manuscript in the Vatican Library (Città del Vaticano, Biblioteca Apostolica Vaticana, Pal. Lat. 24), along with fragments of various other classical authors, portions of two previously unknown works of the Younger Seneca, a treatise Quomodo amicitia continenda sit and the opening lines of a work On the Life of his Father (De uita patris). ${ }^{42}$ In 1820, Niebuhr published an edition of the texts he had found. ${ }^{43}$ Studemund published an improved edition of these Seneca fragments in 1888, and his text of the De uita patris fragment has been followed in subsequent discussions and relevant editions ( $\mathrm{Ap}$ pendix - T1). ${ }^{44}$

The fragment of the De uita patris provides our only direct evidence that the Elder Seneca wrote Histories. The fragment's opening words show that the Histories had not yet been published, and it goes on to speak of the work as follows: quisquis legisset eius historias ab initio bellorum ciuilium, unde primum ueritas retro abiit, paene usque ad mortis suae diem, magno aestimasset scire, quibus natus esset parentibus ille qui res Roman<as ....> ('Whoever had read his Histories from the beginning of the civil wars, when truth first receded, almost up to the day of his death, would have thought it valuable to know from what parents came the man who [recorded] Roman affairs ....'). Other evidence indicates that the Elder Seneca died early in the reign of Gaius, $c$. AD $39 .{ }^{45}$ The fragment's statement that the Histories' coverage extended 'almost up to the day of his death' thus implies that it continued to around the death of Tiberius, and Niebuhr in his edition suggested that Suetonius' citation of 'Seneca' for an account of Tiberius' death (Tib. 73.2; Appendix - F1) refers not, as previously supposed, to the Younger Seneca, but to his father's Histories. Niebuhr also argued that the Younger Seneca's statement that his father's Histories ran 'from the beginning of the civil wars' must

42 On Niebuhr's discovery see Winkworth (1852) 32, 68; Walther (1993) 501; Murray (2010) 242. On the manuscript see Fohlen (1979).

43 For the fragment of the De uita patris see Niebuhr (1820) 103-104.

44 Studemund (1888) XXIII-IV, XXXI-II; Peter (1906) 98; Vottero (1998) fr. 97; FRHist 74 T1.

45 Sussman (1978) 23-24. 
mean that the work's starting point was the outbreak of the civil war between Caesar and Pompey in 49 BC.

Soon after Niebuhr's publication, Mai argued that Lactantius' citation (inst. 7.15.14; Appendix - F2) of 'Seneca' for an analysis of Roman history using the biological metaphor of successive ages (infantia, pueritia, adulescentia, iuuentus, senectus) should also be attributed not to the Younger Seneca, but to his father's Histories. ${ }^{46}$ Some sixty years later, Rossbach used Lactantius' evidence to propound a conception of the scope and significance of the Elder Seneca's Histories which was radically different from Niebuhr's (Rossbach 1888, 161-173). The Younger Seneca's statement that his father began his history at the point 'when the retreat from truth first began', must, Rossbach argued, imply that he 'will have narrated all the civil wars of the Roman people which the Roman historians customarily report as starting from the death of Tiberius Gracchus' ${ }^{47}$ His work will accordingly have had the same scope as Florus' second book and Appian's Emphylia. The Lactantius passage, Rossbach claimed, must show that Florus drew his conception of the ages of the Roman people from the Elder Seneca's Histories, and Florus probably used the work not just for this, but as his main source for his account of the civil wars in his second book, and perhaps also in his first book, since Seneca may have prefaced his full narrative of the Romans' civil wars with a summary account of their external wars. The Elder Seneca's work is also likely, Rossbach maintained, to have been drawn on extensively in the writings of his son and his grandson Lucan, and the striking verbal similarities between Lucan and Florus should be explained as borrowings not by Florus from Lucan, but by both writers from Seneca's Histories. Rossbach reasserted these claims in several subsequent publications, ${ }^{48}$ and in his final contribution he added the further proposition that the Elder Seneca's Histories had served as structural model not only for Florus, but also for Appian. ${ }^{49}$

All Rossbach's contentions were soon challenged by Klotz, who argued that both Suetonius' and Lactantius' citations refer to lost works of the Younger Seneca; the discrepancies between the versions of the ages of the Roman people given by Florus and Lactantius show that Seneca was not Florus' source; and Florus' verbal similarities with Lucan were direct borrowings. Klotz also maintained that the Younger Seneca's language in the De uita patris fragment implies that he

46 Mai (1828) 157.

47 Rossbach (1888) 163: Seneca ... omnia bella civilia populi Romani narraverit quae iam a morte Tiberii Gracchi initium cepisse historici Romani tradere solent.

48 Rossbach (1894) 2239; (1896) LIII-LVIII; (1903); (1909) 2761-2766.

49 Rossbach (1909) 2762. 
never brought his father's Histories to publication, and so was the only writer who had access to them. ${ }^{50}$

Klotz's claims too were soon questioned, and have remained in dispute. Although there have been notable doubters, the majority of subsequent writers have held that the Elder Seneca's Histories were published, that Suetonius' and Lactantius' citations refer to this work, and that it was the source for Florus' conception of the ages of the Roman people. ${ }^{51}$ It was, however, a long time before any scholar took up Rossbach's further contentions that the Histories started with the tribunate of Tiberius Gracchus and were used by Florus and Appian as the model for the structure of their works.

In 1964 Hahn adopted Rossbach's thesis in its main lines and presented it in revised form, with much greater emphasis on Appian. ${ }^{52}$ Like Rossbach, Hahn argued that Seneca's Histories started from Tiberius Gracchus and were the common source for the shared structural features of Florus' second book and Appian's Emphylia. In addition, he identified Seneca's work as Appian's main source for the narrative of the Emphylia, following a suggestion made in passing by Piganiol. ${ }^{53}$ Accepting the testimony of the majority of the manuscripts that Florus' gentilicium was Annaeus, ${ }^{54} \mathrm{Hahn}$ went on to claim that Florus belonged to a family circle with the two Senecas and Lucan, and that shared material deriving from the Elder Seneca's Histories could be identified in the works of the other three members of the group and in Appian.

50 Klotz (1901). Klotz later made some modifications to his views: see Klotz (1909), (1913) 554555; Griffin (1972) 10 n. 108.

51 Sceptics include Syme (1958a) 277; Griffin (1972) 10-11, 19, (1992) 33, 509; Levick in FRHist I 506-507, III 596. For listing of scholars' views on the identity of the Seneca cited in this passage of Lactantius see Lausberg (1989) 1957 n. 295; Vottero (1998) 78; Freund (2009) 425-428; add Woodman (2010b) 55-59 for the Younger Seneca.

52 Hahn (1964), with further argument for the Elder Seneca as the common source for Florus and Lactantius on the ages of Rome at Hahn (1965). Hahn did not take up Rossbach's suggestion that the Elder Seneca's Histories included an opening survey of Roman external wars, and held that Florus used Livy as his main narrative source directly, rather than through Seneca, as supposed by Rossbach.

53 Piganiol (1935); (1962) 153. For criticism of Piganiol's suggestion see Gabba (1956) 113-115.

54 On Florus' gentilicium see Jal (1967) CXII-III; Bessone (1993b) 105-106. 
Hahn's thesis won early support from Zecchini, ${ }^{55}$ but was also subjected to widespread criticism. ${ }^{56}$ Hahn himself later propounded a quite different approach to the problems of Appian's sources, and reverted to the conventional view that Pollio was his main source for Emphylia Books $2-5 .{ }^{57}$ Recently, however, Hahn's original view has found fresh advocates. Westall, in a study of Appian's sources in the Emphylia challenging his supposed dependence on Pollio, has claimed that the Elder Seneca's Histories were 'Appian's principal Latin source' and the source of the structural features common to Appian and Florus. ${ }^{58}$ In a monograph on Appian and Augustus, Canfora has restated the views of Rossbach and Hahn (1964) at length, arguing that Appian should be seen as linked to the 'circle of the Annaei' comprising the two Senecas, Lucan and Florus; that the Elder Seneca's Histories served as both the structural model and the main source for both Florus' second book and Appian's Emphylia; and that, while much of Florus' material derives from Livy and of Appian's from Pollio, their access to these writers came indirectly through the Elder Seneca. ${ }^{59}$ Canfora also adds a further element, arguing that from Emphylia Book 3, Appian used Augustus' autobiography as a second main source alongside Seneca's Histories and as a counterpoise. ${ }^{60}$ Canfora's arguments have already won some support. ${ }^{61}$

The identification of P.Herc. 1067 as part of the Elder Seneca's Histories has put it beyond dispute that the work was brought to publication, presumably by his son. The latter's De uita patris may well have been composed as an introduction to the published Histories. ${ }^{62}$

55 Zecchini (1977). Zecchini offers as a further proof of common derivation the shared error of Appian and the younger Seneca on Bibulus' praenomen, but for refutation see Hose (1994) 162 n.12.

56 E.g. Griffin (1972) 10 n. 115; Hose (1994) 162-165; Hinard (2008) CCXVII-VIII (cet étrange théorie); Levick in FRHist I 506-508.

57 Hahn (1982), especially 275. See supra n. 29.

58 Westall (2015) 158-60. In an earlier study Westall placed the emphasis instead on Livy, whom he identified as the source of the common material in Appian and Plutarch (Westall (2013), especially 112-113).

59 Canfora (2015) 138-213. For an earlier statement see Canfora 2000. The 'circle of the Annaei', and indirect use of Livy and Pollio: Canfora (2015) especially 160, 210-213. Canfora's aspersions on the editors of FRHist are gratuitously offensive: Canfora (2015) 143-144, 159-160, 187-188, 300.

60 Canfora (2015) 216-290.

61 Carsana (2018), who, however, argues for Appian's making direct use of Pollio as well as of the Elder Seneca; Mazzoli and Renda, this volume. For a critique of Canfora (2015) see Smith (forthcoming).

62 See Sussman (1978) 144 and in the present volume supra 149; Vottero (1998) 76-77. 
Some of the other points in dispute do not seem to me capable of definitive resolution. The identity of the Seneca cited by Suetonius on the death of Tiberius or by Lactantius on the ages of Rome cannot be established with certainty. The father's history would provide a suitable context for each citation, but so could lost philosophical works by the son. Elsewhere in these authors' works references to Seneca relate to the son, but this is not a decisive objection to attributing these citations to the father, particularly for Lactantius, who may not have distinguished between them. ${ }^{63}$ Similarly, Florus' source for his conception of the ages of the Roman people cannot be definitively identified. The Seneca cited by Lactantius (whether the father or the son) could have been Florus' source, since the divergences between Florus' and Lactantius' versions could result from their own modifications of what they found in their source. However, the concept is unlikely to have originated with Lactantius' Seneca, and so Florus may have drawn it from another source. ${ }^{64}$

It is likely that the Younger Seneca drew on his father's Histories for some of his allusions to the recent past. ${ }^{65}$ Whether, and, if so, to what extent Lucan, Florus or Appian drew on the Elder Seneca's Histories for this or other material cannot be determined. None of the evidence amassed by Rossbach, Hahn and Canfora provides proof of such debts. There is no need to postulate common derivation from Seneca to account for the similarities between Lucan and Florus: these may be direct borrowings from Lucan by Florus or shared debt to Livy, whom both writers used as their main source. ${ }^{66}$ The Elder Seneca may well be Florus' source for his conception of the ages of the Roman people, but, if so, this would tell us nothing about Appian, since there is no trace of this biological metaphor in his work.

The best interpretation of the Younger Seneca's statement that his father's Histories ran 'from the beginning of the civil wars' ( $a b$ initio bellorum ciuilium) remains the one originally proposed by Niebuhr, that the work started with the civil war between Pompey and Caesar. This would have been a natural starting point for the Elder Seneca: beginning there made his history an account of the times through which he himself had lived. It has been objected that the Younger Seneca's use of the plural bellorum ciuilium implies that the work covered all the

63 Bocciolini Palagi (1978) 220-222.

64 The concept may already have featured in Varro's De uita populi Romani: see further Häussler (1964); Bessone (2008) 49-87; Pittà (2015) 269-274.

65 Castiglioni (1928) 456-7; Canfora (2015) 172-179.

66 For Lucan's use of Livy as his main source see Pichon (1912) 51-104; Lintott (1971) 488-489 n. 6; Radicke (2004) 9-43. 
Roman civil wars, ${ }^{67}$ but this is not cogent. Caesar's conflict with Pompey inaugurated some twenty years of successive, wide-ranging civil wars, ended only by the final victory of Octavian/Augustus, which enabled him to make the proud boast that he had 'extinguished civil wars'. ${ }^{68}$ The use of the plural form for the persistent civil warfare of the period is not uncommon both in the Younger Seneca's works and elsewhere, and the Elder Seneca himself employs it when he tells us that in his youth he was prevented from leaving his native Corduba by 'the fury of civil wars which was then ranging across the whole world'. ${ }^{69}$

The Younger Seneca goes on to speak of the Histories as starting 'from the point when truth first receded' (unde primum ueritas retro abiit). The remark must be his own, but probably reflects a view expressed in his father's work, perhaps in a conventional prefatory commitment to veracity. This too fits well with a Caesarian starting point. Tacitus at the start of his Histories observes that, after the Actium war and the monarchy to which it led, 'truth was damaged in various ways'. ${ }^{70}$ If monarchy was the enemy of truth, Caesar's civil war, which led first to his monarchy and ultimately, after further civil wars, to its enduring establishment by Augustus, could appropriately be regarded as the point at which the regression from truth began. ${ }^{71}$

If this identification of his starting point is correct, the Elder Seneca's detailed narrative will have begun with the outbreak of the civil war in $49 \mathrm{BC}$, but this may have been preceded not only by a preface, which may have included the biological metaphor of the ages of Rome (if Lactantius' citation refers to this work), but also by an overview of earlier events to explain the origins of the conflict. Such a procedure would have been comparable to that of Sallust in his Histories: Sallust announced the scope of his work as 'the deeds of the Roman people at home and at war in and after the consulship of M. Lepidus and Q. Catulus [78 BC]' (1.1), but this main narrative was preceded both by a preface $(1.1-18$ Maurenbrecher $=1.1-$ 16 Ramsey) and by an account of events from the outbreak of the Social War in 91 BC on (1.19-53 Maurenbrecher $=1.17-47$ Ramsey). If Seneca's detailed narrative

67 So Hahn (1964) 177; Canfora (2015) 140.

$68 R G$ 34.1: [b]el[la ciuil]ia exstinxeram; cf. Vell. 2.89.3: finita uicesimo anno bella ciuilia.

69 Sen. contr. 1 pref. 11: bellorum ciuilium furor, qui tunc orbem totum peruagabatur. See Castiglioni (1928) 458-460; Griffin (1970) 9; Vottero (1998) 79-80.

70 Tac. hist. 1.1.1: ueritas pluribus modis infracta. Cf. Sen. benef. 6.32.4; Suet. Claud. 41.2; D.C. 53.19.1-4.

71 Sussman (1978) 142-146 interprets ueritas in this phrase as 'righteousness' and uses this to argue for a Gracchan starting point for the Histories (see also in the present volume supra 172175), but this cannot be the term's meaning here: so rightly Lausberg (1989) 1938 n. 217; Levick in FRHist I 506 n. 18. 
started in 49, a preliminary overview of this kind could well have begun with the formation of the alliance between Caesar, Pompey and Crassus in 60 BC, which, as we have seen, was also the starting point of Pollio's history, but seems unlikely to have treated events much earlier than 60 in any detail.

If, as maintained by Rossbach and his successors, the Younger Seneca's statement that his father's Histories ran 'from the beginning of the civil wars' should be taken as implying that it included the civil wars of the 80s BC, the work's formal starting point would have been the year 88 and Sulla's march on Rome in that year. The Romans, who have bequeathed the concept of 'civil war' to us, drew a sharp distinction between such wars, in which Roman armies were engaged, and other violent disturbances, such as the tribunician upheavals from Tiberius Gracchus on, and thus, as Appian clearly stated (n. 16), Sulla's march was the first civil war. The term bellum ciuile probably came into use in the 80s or 70s: by the ensuing decades, from which our first attestations date, it is firmly established as a designation for the wars between Sulla and the Mariani. ${ }^{72}$

The first outbreak of civil war in 88 would in fact have made an awkward starting point for a history, since it arose from and was intimately connected with the immediately preceding Social War. The Social War itself would have afforded a much more natural starting point, and had already served for this purpose for the histories of Sisenna and Lucceius. ${ }^{73}$ 'From the beginning of the civil wars' would also have been an odd way of describing a history whose detailed narrative began in the 80s, but then continued over the ensuing three decades in which civil war played relatively little part. ${ }^{74}$

If the Elder Seneca did begin his detailed narrative in 88 , it is likely that he will have prefaced it by an explanatory overview of some preceding events. Such an overview would probably have covered at least the Social War. ${ }^{75}$ It may have extended to some earlier events as well, but it cannot be taken for granted that it would have included narratives of the tribunates of the Gracchi and Saturninus, as Rossbach and his successors assume. It is true that Florus and Appian narrated those episodes (termed seditiones by Florus, staseis by Appian) before going on to the Social War and the ensuing civil wars. In doing so they were presenting an

72 Cic. Manil. 28, fam. 5.12.2. On the origins of the concept of bellum ciuile see now Armitage (2017) 31-90; Lange/Vervaet 2019a; van der Blom 2019. On Sulla's march as the decisive innovation see Flower (2010).

73 Sisenna: FRHist I 308, 312 (John Briscoe). Lucceius: Cic. fam. 5.12.2 (= FRHist 30 T1).

74 Cf. Levick in FRHist I 506, not refuted by Canfora (2015) 187-188.

75 It is possible that Sisenna's treatment of the Social War had this character: Velleius describes his history as opus belli ciuilis Sullanique (Vell. 2.9.5 = FRHist 26 T13). 
interpretation, which can already be traced in Sallust and Velleius, of Roman political disintegration as progressing from urban disorder to civil war. ${ }^{76}$ However, as we saw in the previous section, Florus and Appian were offering accounts not just of the Romans' civil wars, but of all their internal upheavals in which blood had been shed, a point which has been obscured by the conventional mistranslation of Appian's book title Emphylia as Civil Wars.

Thus what we are told of the Elder Seneca's starting point does not afford Rossbach and his followers the support which they claim: the most plausible interpretation of his son's description of the Histories as starting 'from the beginning of the civil wars' is that they began with the war between Caesar and Pompey, and, even if the Younger Seneca's reference is instead to the Sullan wars, it does not necessarily follow that his father's work began effectively with Tiberius Gracchus. A further and, in my view, fatal objection to the arguments of Rossbach, Hahn and Canfora is posed by what we are told of the scope and endpoint of the Histories.

The Younger Seneca tells us that his father's Histories dealt with res Roman<as $>$ ('Roman affairs') and that its coverage continued 'almost up to the day of his death'. Other indications provide confirmation of its scope: if Suetonius' citation relates to the Histories, it extended up to Tiberius' death in $\mathrm{AD} 37$, and P.Herc. 1067 has now been shown to contain part of its treatment of the reigns of Augustus and/or Tiberius. ${ }^{77}$ Thus the work continued long after the victories over Antony and Cleopatra which brought the civil wars to an end, covering the whole of the long reign of Augustus and either all or almost all of the reign of Tiberius.

Canfora's comments on the scope of the Histories betray embarrassment. ${ }^{78}$ The Elder Seneca, he assures us, 'volle assumere come oggetto della sua opera il tema cruciale e incandescente delle guerre civili romane'. His original plan may have been to stop at Actium. By continuing the work so far beyond that point, he turned it into 'una "storia generale" (modello Historiae)', but the theme of civil wars remained its 'filo conduttore'. The change of plan was perhaps prompted by the underlying tensions and instability Seneca perceived in the regimes of $\mathrm{Au}$ gustus and Tiberius: he may have discerned 'un possibile riaccendersi del conflitto'. As a result, Seneca's work became 'una storia delle vicende politiche e militari al tempo delle guerre civili’ (Canfora's italics).

76 Sall. hist. 1.12 (remoto metu Punico ...plurumae turbae, seditiones et ad postremum bella ciuilia orta sunt); Vell. 2.3.3; cf. Jal (1963) 27-32.

77 See Piano (2017a), and the contributions by Piano and Scappaticcio in this volume.

78 Canfora (2015) 145, 169-170. 
This fantasy is as redundant as it is implausible. The Histories' scope and the Younger Seneca's description of their subject matter as res Roman<as > carry a clear implication: the work was not a history of the civil wars, but a Roman history which took 'the beginning of the civil wars' as its starting point. The Histories evidently belonged to what by the Elder Seneca's time was one of the two main, long-established genres of Roman historical writing, namely histories of the deeds of the Roman people at home and at war which, instead of starting from the foundation of the city, covered just a limited recent period. This was the mode which had been pioneered by Sempronius Asellio and probably Fannius, had been continued by Sisenna, Sallust (in his Histories), Pollio, Cremutius Cordus and Aufidius Bassus, and was to reach its culmination with Tacitus.

The Elder Seneca's Histories were thus not an innovatively designed war monograph, but a Roman history of a traditional type, general in scope but restricted to a period of recent history. The Caesarian starting point showed no originality: Pollio had done much the same, and so too may Cremutius Cordus and Aufidius Bassus. In their structure too the Histories probably followed tradition. Sallust and Tacitus organized their works of this type by the consular year, and, little as we know about them, the same is likely to have been true of the rest. Thus Seneca too probably used annalistic organization for his Histories, although, like others, he will have applied it flexibly when handling the complexities of the Caesarian and triumviral civil wars. ${ }^{79}$

Traditional Roman historiography followed linear chronology, in which the material was organized by consular years and domestic and external sections normally alternated within each year narrative, and the Elder Seneca's Histories probably conformed to this model. The works of Florus and Appian, as we have seen, depart radically from this pattern in ways which have notable features in common. Both their works separate the treatment of external and domestic events and limit their coverage of domestic events to upheavals involving bloodshed: each writer first narrates the external wars of the Republic, then turns to the internal upheavals from Tiberius Gracchus on, and concludes with external wars in the imperial period. There is no good reason to suppose that the Elder Seneca's Histories served in any way as a model for these structural innovations. The only ground for this conjecture has been the, in all probability mistaken, belief that the work started with Tiberius Gracchus. Even if this were correct, its structure would still not have provided the model for Florus and Appian, unless, like Rossbach, we were to make the further assumption that Seneca first provided an overview of the Romans' external wars before going on to his account of their

79 On annalistic organization in Roman historiography see Rich (2011); (2018). 
internal discords from the Gracchi on. Nor can Seneca have had any responsibility for the other structural feature shared by Florus and Appian, namely their periodization of the nine hundred years of Roman history, ending in the nearly two hundred years from the establishment of monarchy to their own time. The Elder Seneca may perhaps have been Florus' source for his other structuring element, the biological metaphor of the ages of Rome, but of this, as we have seen, there is no trace in Appian.

\section{Conclusion}

The conclusions for which this paper has argued may be summarized as follows.

The Elder Seneca's Histories began with the war between Caesar and Pompey, and conformed to the well established pattern of a history of the deeds of the Roman people at home and at war covering a limited period of recent history. It had much in common with the historical works of his near contemporaries Pollio, Cremutius Cordus and Aufidius Bassus: all these histories will have been on an ample, multi-book scale, and they probably had similar starting points and organized their material in the traditional fashion by the consular year. Although the Elder Seneca's Histories may possibly have been Florus' source for the biological metaphor of the ages of Rome, there is no good reason to suppose that Seneca's work served in any way as a model for the radical structural features shared by the works of Florus and Appian.

The close structural similarities between Florus and Appian are too close for coincidence, and must reflect a direct debt of one writer to the other rather than deriving from a common source. Unfortunately, there can be no certainty as to which wrote first.

Both Cassius Dio and Appian compiled notes and drafts from their reading, and in the final phase of composition worked mainly from these materials rather than from the originals, and this technique helps to explain the considerable freedom with which they handled their sources. In other respects, however, their methods differed widely, in accordance with their works' distinctive aims and structures.

Dio's work conformed to the oldest Roman historiographical pattern, the history of the deeds of the Roman people from the foundation of the city to the author's own time, and he aspired also to produce a history which could stand comparison with the Greek classics. He boasts of his wide reading, and for most of his work probably drew on multiple sources. For the period it covered - the Caesarian and triumviral civil wars and the reigns of Augustus and Tiberius - the Elder 
Seneca's history may have served as one of his sources. In particular, Dio may have found it a helpful source of information on the politics of the imperial court.

The chief novelty of Appian's Roman history was his reorganization of his material on a predominantly ethno-regional structure. He was thus under no obligation to work consistently from multiple sources, and for much of his account of Rome's external wars he can be shown to have worked from a single main source - Dionysius down to 265 BC and Polybius for the period 200-146 BC. Posidonius may have served him in the same way for the later second and early first century BC, both in the external books and in the first book of the Emphylia. Appian's account of the period from Caesar's death on in the Emphylia is on a more ample scale and appears to have drawn on a wider range of sources. One of those sources could perhaps have been the Histories of the Elder Seneca, but, if Appian did make use of that work, it has left no identifiable trace. 
